Papers and Proceedings of the Royal Society of Tasmania, Vol.109, 1975.

(ms. received 23.10 .1974 )

\title{
PHYTOSOCIOLOGICAL ANALYSIS OF THE VEGETATION OF LAGOON BEACH, TASMANIA
}

\author{
by J.B. Kirkpatrick
}

Geography Department, University of Tasmania

(with two tables, four text-figures and four plates)

\section{ABSTRACT}

The vegetation of the Lagoon Beach area is mapped and described. Classification and ordination of thirty-five randomly located quadrats, and Chi analysis of association between species, reveal three main species/stand groups. The wombat-grazed closed-herbfields dominated by Samolus repens and Schoenus nitens form one strong group associated with the lagoonal flats. A second group consists of stands which include characteristic heath species such as Casuarina monilifera and Hypolaena fastigiata. A third, less well-defined group consists mainly of Eucalyptus viminalis open forests with an understory characteristically dominated by Ptemidium esculentum. The factors that could be responsible for the differentiation of the vegetation of the area are discussed, and a species 1 ist is appended.

\section{INTRODUCTION}

The clearing of Tasmanian native vegetation has accelerated over recent years, especially in coastal areas of relatively little relief. Yet, our knowledge of the ecology and floristics of those areas most prone to clearing is minimal. The northwestern tip of the Tasman Peninsula is one area showing many signs of impending conversion to smiling pastures and uncontrolled shack development. At present (September 1974) the only parts of the area not privately owned are a narrow coastal reserve and the Saltwater River Scenic Reserve of 214 ha. Neither of these reserves include the heath or lagoon flat communities found in the area described in this article. The study area is located on the west coast of the Tasman Peninsula opposite Sloping Island (fig. 1).

No climatic data are available, but the mean annual rainfall at Lagoon Beach is probably approximately $650 \mathrm{~mm}$, distributed reasonably evenly throughout the year, with the highest monthly totals being received in late autumn-early winter and spring. Frosts are almost certainly rare.

The area is underlain by Triassic sandstone which has been largely covered by sand sheets, dunes and lagoon deposits, but which outcrops in the cliffs in the north of the study area. The area includes two lagoons surrounded by flats which are separated by a slightly elevated sand sheet, and cut off from the sea by a retreating foredune. To both the north and the south of the lagoons and flats the 1 and rises gently to approximately $30 \mathrm{~m}$.

The soils found in the area are predominantly deep sands. The soils of the flats and foredune exhibit little horizon development apart from some surface darkening by organic matter. In the case of the flats this lack of horizonation probably has resulted from periodic inundation, and in the case of the foredune from the youth of the parent material. Elsewhere the soils are sand podzols with a well-developed and deep bleached horizon and a marked zone of concentration of iron and humus. The soils of the flats and seaward slopes of the foredune are neutral to slightly alkaline in reaction, while in the remainder of the study area the soils are acidic. 


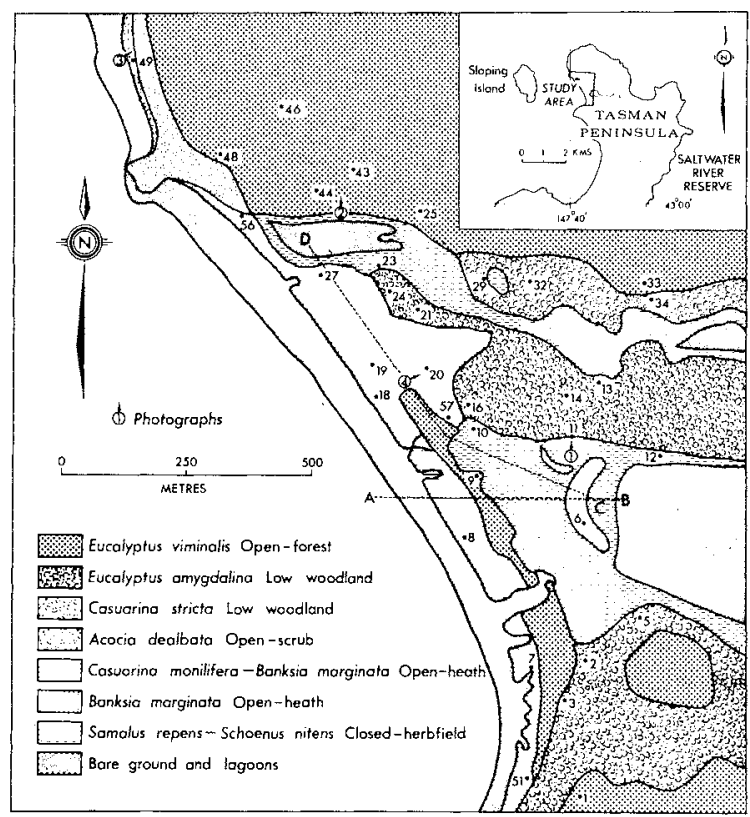

FIG. 1. - Vegetation and location map. The locations of sample areas, leveling traverses and photographs are shown.

\section{ME'THODS}

Thirty five sample areas were located randomly throughout the study area (fig. 1). All species with aerial organs above these $10 \mathrm{x}$ $10 \mathrm{~m}$ squares were recorded and collected. The rooted frequency, density and coverage of each species occurring within ten one square $m$ quadrats, located randomly within each sample area, were recorded. With species of rhizomatous habit, such as Pteridium esculentum, the number of unconnected aerial shoots rather than the actual number of plants was recorded. Coverage was estimated to the nearest ten percent. The coverage and density figures for the ten quadrats were averaged to give a sample area mean.

Species not found within the sample areas were collected in September 1972 when sampling took place and in December 1972. Specimens were identified where possible to the species level (Appendix). The vegetation of the area was mapped according to the structural classification of Specht (1970) from field data and aerial photograph analysis.

The dimensional relationships between all species occurring in seven or more sample areas were explored using uncorrected $\mathrm{Chi}^{2}$ as a measure of association. The use of Yates correction in this context, even although cell values are low, would have resulted in a conservative estimate of association (Grizzle 1967).

In establishing stand relationships an importance value was calculated for each species in each stand from the frequency, coverage and density values. Relative values for each of the three abundance measures were calculated by totalling the absolute values for all species in a stand and expressing the contribution of each single species as a percentage. The importance value was derived from the addition of the relative frequency, relative coverage and relative density values, and the division of this total by three.

The stands were then classified using the Zurich-Montpellier technique (Bridgewater 1971). However, the groups recognized through the use of this technique have not been formally named, as data from such a small area are almost certainly insufficient to make taxonomic decisions.

Stand relationships were further analyzed using the polar ordination technique of Bray and Curtis (1957). This technique has been shown to be more suitable for phytosociological data than the currently more fashionable principal components analysis (Gauch and Whittaker 1972). The polar stands for the $x$ axis were selected on the basis of soil drainage conditions and distance values. The poles for the $y$ axis were selected to give a contrast in exposure to salt spray, and on the basis of distance values. 


\title{
J.B. Kirkpatrick
}

\author{
RESULTS AND DISCUSSION
}

\section{Structural Variation}

The structure of the vegetation of the study area is mapped in figure 1 . Structural boundaries are generally relatively sharp, especially that between the herbfield and other structural units (p1ates 1 and 2). However, the boundaries between open-heath, low woodland and open-forest are best considered ecotones whose width is greater than the "to scale" width of the lines dividing them on the map. The dominant species within each unit are indicated in the map key.

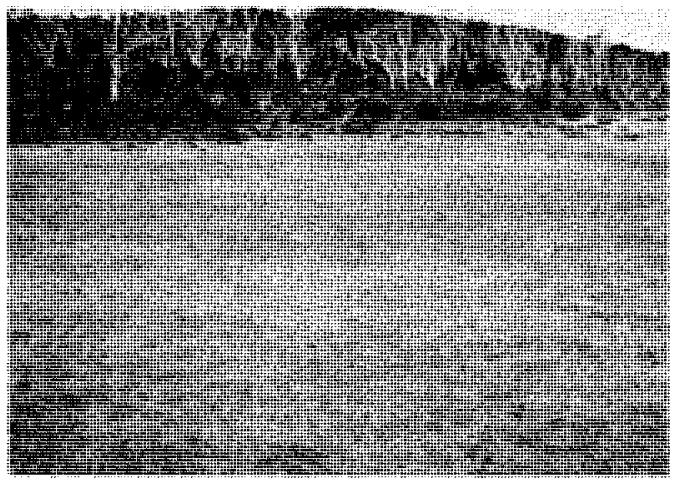

PLATE 1. - The closed-herbfield with the emergent shrub zone in the middleground and low wood 1 and in the background.

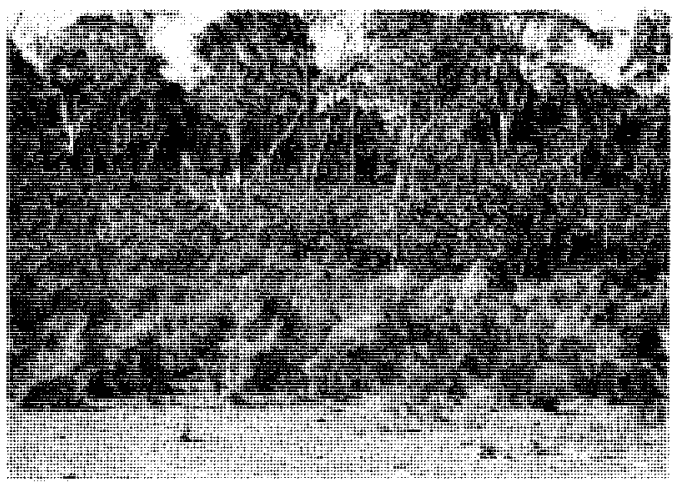

PLATE 2. - The boundary between the closedherbfield and open-forest. Note the density of wombat scats in the foreground and of pteridium esculentum in the background.

\section{Species Relationships}

The dimensional relationships diagram (fig. 2) reveals three major groups of species. The small group at the base of the diagram consists of the three species included from the herbfield. These species are linked through Epacris Zanuginosa and Bossiaea prostrata to the group of species found predominantly in the heath and wood1and. $E$. Zanuginosa and Leptospermum scoparium are logically located in an intermediate position as they tend to be found in the wetter heaths adjacent to the herbfield. The strong group of heath species has a number of links to the more diffuse group of species characteristic of the open-scrub and open-forest.

\section{St and Re1ationships}

The sample areas divide into two major groups, on the basis of their floristic composition. The first and smaller group is characterized by the presence of Samolus repens, Schoenus nitens, Pultenaea dentata, Leptospermum scoparium and Gnaphalium candidissimum (table 1). Only two of the sample areas in this group (10 and 12) are located entirely on the lagoonal flat closed-herbfield, but the others are located marginally to this structural type.

The most constant species of the second group are Pteridium esculentum, Banksia marginata, Aotus ericoides, Haloragis tetragyna and Hibbertia fasciculata (table 2). However, of these species only Pteridium esculentum and HaZoragis tetragyna are reasonably faithful. Three subgroups of sample areas can be recognized within the second group (table 2). The strongest subgroup is characterized by Hypolaena fastigiata, Cassytha glabelza, Eucalyptus amygdalina, Dizlwynia glaberrima, Lepidosperma concavum and stylidium graminifolizm, the same group of species strongly interlinked in figure 3. Similarly, the open-scrub and open-forest group of species evident in figure 3 characterize another less wel1-defined group of sample areas. These species 
are Eucalyptus viminalis, Kennedia prostrata, Hibbertia acicularis, Lomandra Zongifolia, Goodenia lanata and Acacia dealbata. The third subgroup of sample areas is characterized by the general absence of the species which characterize the first two subgroups.

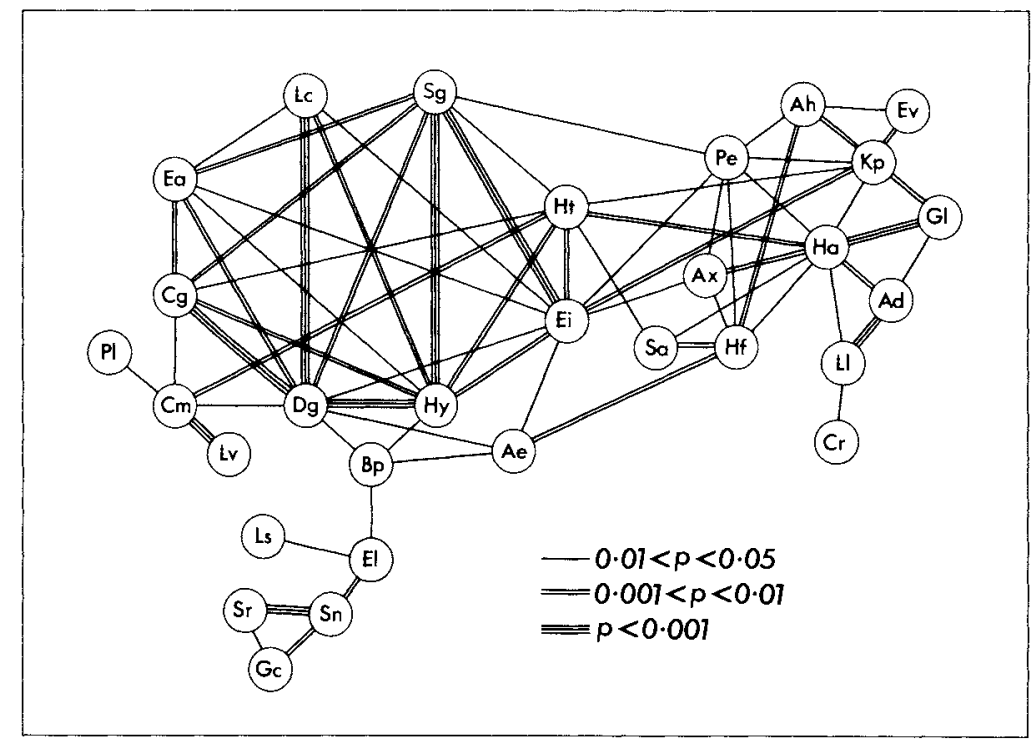

FIG. 2. - The dimensional relationships of species occurring in seven or more sample areas.

$\mathrm{Ad}=$ Acacia dealbata, Ae = Aotus ericoides, Ah = Astroloma humifusum, $\mathrm{Ax}=$ Amperea xiphoctada, $\mathrm{Bp}=$ Bossiaea prostrata, $\mathrm{Cg}=$ Cassytha glabelza, $\mathrm{Cm}=$ Casurrina monilifera, $\mathrm{Cr}=$ Carpobrotus rossi, $\mathrm{Dg}=$ Dillwynia glaberrima, Ea = Eucalyptus amygdalina, Ei = Epacris impressa, $\mathrm{El}=$ Epacris Zanuginosa, Ev = Eucalyptus viminalis, $\mathrm{Gc}=$ Gnaphalium candidissimum, G1 = Goodenia Lanata, Ha = Hibbertia acicularis, Hf = Hibbertia fasciculata, Ht = Haloragis tetragyna, $\mathrm{Hy}=$ Hypolaena fastigiata, $\mathrm{Kp}=$ Kennedia prostrata, Lc = Lepidosperma concavum, L1 = Lomandra Zongifolia, Ls = Leptospermum scoparium, $\mathrm{Lv}=$ Leucopogon virgatus, $\mathrm{Pe}=$ Pteridium esculentum, $\mathrm{P1}=$ Pimelea Zinifolia, Sa = Styphelia adscendens, $\mathrm{Sg}=$ Stylidium graminifolium, $\mathrm{Sn}=$ Schoenus nitens, $\mathrm{Sr}=$ Somolus repens.

Continuous variation between stands is evidenced by the results of polar ordination (fig. 3). The sample areas in the first group are located contiguously, but there is no marked break between this group and the second group. The sample areas in the subgroups of the second group are not located entirely contiguously, probably because the species whose presence or absence define these subgroups do not generally account for much of the total relative importance values for the sample areas.

Several stands that were neither similar in their floristic composition to each other nor to the two major groups were excluded from the tables, but their locations are shown on the ordination (fig. 3).

Envirommental Relationships

Although the primary objective of the study was to describe the vegetation of the area, observations were also made on vegetation-environment relationships. The major factors that seem important ir differentiating the vegetation of the area are soil drainage conditions, soil fertility, the influence of saltspray, and grazing. These factors will be discussed in relation to the lagoonal flats, and the remainder of the study area. 
J.B. Kirkpatrick

Four zones can be distinguished in the lagoonal flats. Triglochlin procera and Vizzarsia reniformis form the first zone, which is separated from the third zone by a bare area. The third zone is the closedherbfield, usually only one or two $\mathrm{cm}$ $\mathrm{high}$, and closely resemb. ling a bowling green (plate 1). In the fourth zone scattered individuals of Pultenaea dentata and Leptospermum scoparium are found emerging from the dense sward of herbs (plate 1). Water relations may control most of the variation in the vegetation of the lagoon and lagoon flat habitats. The first zone occurs in a semiaquatic habitat where plant roots are probably almost permanently waterlogged. The bare zone may be the result of frequent alternation of inundation and exposure. One of the effects of this alternation may be the accumulation of salt in the soils of this zone during exposure periods, as the waters of the lagoons are brackish. The third and fourth zones may be inundated only rarely, but the watertable is probably always close enough to the surface to allow plants ready access to moisture. The main evidence for periodic inundation of the closed-herbfield is the nature of the soils. They are neutral to slightly alkaline in reaction, indicating perhaps an accumulation of salt as a result of occasional inundation with brackish water, and they lack horizonation, which may indicate either youth or prevention of sustained leaching through periodic inundation. The relationships between topography, watertable depth and vegetation across two dumpy-levelled transects in the study area are shown in figure 4. The watertable depths are those found in September 1972 after a relatively dry winter.

Although drainage and watertable conditions are probably most important in determining the boundary between the closed-herbfield and other communities, intensive grazing by wombats may play a strong part in maintaining the structure of the vegetation and preventing shrub invasion. The density of wombat scats on the herbfield can be gauged from plate 2. Dramatic changes in the structure and species composition of 
TABLE 1

RELATIVE IMPORTANCE VALUES

\begin{tabular}{lrrrrrrr}
\multicolumn{1}{c}{ Sample area } & 10 & 12 & 11 & 6 & 23 & 29 & \%I* \\
Scmolus repens & 28 & 21 & 25 & 24 & 13 & 33 & 85 \\
Schoenus nitens & 25 & 38 & 32 & - & 10 & 18 & 90 \\
Pultenaea dentata & 7 & 5 & 14 & 2 & 1 & - & 100 \\
Leptospermum scoparium & - & 3 & 9 & 6 & 3 & 12 & 34 \\
Gnaphalium candidissimum & 6 & 4 & 3 & 1 & 13 & - & 42 \\
Hydrocotyle hirta & 22 & 1 & - & 17 & - & - & 91 \\
Cotula reptans & 1 & 26 & - & 11 & - & - & 97 \\
Haloragis micrantha & 1 & 1 & 1 & - & - & - & 100 \\
Acacia verticillata & - & 1 & - & 9 & 1 & - & 23 \\
Hibbertia fasciculata & - & - & 2 & 2 & 15 & - & 10 \\
Banksia marginata & 1 & - & - & 11 & 3 & 5 & 9 \\
Aotus ericoides & - & - & 2 & 5 & 16 & - & 18 \\
Epacris lanuginosa & - & - & 5 & - & 1 & 17 & 27
\end{tabular}

TABLE 2

(continued from opposite page)

Additional Species: Acaena anserinifolia (6), Acacia dealbata (12), Astroloma hwifusum $(6,23)$, Billardiera Zongiflora (29), Bossiaea cinerea (11), Carpobrotus rossii $(6,23)$, Casuarina monilifera (23), Centrolepis fascicularis $(10,23)$, Daviesia ulicifolia (12), Dichondra repens (10), Eucalyptus amygdalina $(11,23), E$. ovata $(23,29)$, E. viminalis (11), Hakea teretifolia (29), Haloragis tetragzna (11), Hypochaeris glabra $(10,12)$, Kennedia prostrata (6), Lepidosperma longitudinale (6), L. concavum (29), Leucopogon ericoides (23), L. virgatus (23), Melaleuca squarrosa (29), Persoonia juniperina (29), Pimelea Iinifolia (29), Pteridium esculentum $(6,23)$, Scaevola hookeri (29), Scirpus nodosus (6), Sprengelia incamata (29), Styphelia adscendens $(23,29)$.

* Total relative importance values in table/total relative importance values for a11 sample areas $\times \frac{100}{1}$. 
TABLE 2

RELATIVE IMPORTANCE VALUES

\section{Samp1e Area}

Banksia marginata Pteridium esculentum Aotus ericoides

HaZoragis tetragyna

Hibbertia fasciculata Casuarina monilifera Leucopogon virgatus Amperea xiphoclada Astroloma humifusum Eucalyptus viminalis Kennedia prostrata Hibbertia acicularis Iomandra Zongifolia Goodenia lanata

Acacia dealbata

Bossiaea cinerea

Viola hederacea

Epacris impressa

Hypolaena fastigiata Cassytha glabezla

Eucalyptus amygdalina Dizluynia glaberrima

Lepidosperma concarrm Stylidium grominifolium Gompholobium huegelii pimelea linifolia

Styphelia adscendens Leucopogon ericoides Lepidosperma Zongitudin-

Carpobrotus rossii oxalis comiculata Bossiaea prostrata Epacris Lanuginosa Leptospermum scoparium Melaleuca squarrosa Leptospermum glaucescens 1

Samolus repens

Schoenus nitens

Acaena anserinifolia $\begin{array}{llllllllllllllllllllllll}43 & 48 & 44 & 1 & 19 & 27 & 18 & 33 & 49 & 9 & 46 & 3 & 2 & 21 & 25 & 14 & 20 & 5 & 13 & 32 & 24 & 16 & 51 & \%\end{array}$

$\begin{array}{lllllllllllllllllllllll}1 & 1 & - & 8 & 12 & 15 & 22 & 1 & 7 & 7 & 12 & 3 & 1 & 2 & 1 & - & 1 & 7 & 20 & 16 & 6 & 2 & 8\end{array}$ $\begin{array}{rrrrrrrrrrrrrrrrrrrrrrrrr}36 & 49 & 26 & 32 & 32 & 15 & 8 & 30 & 12 & 20 & 44 & 13 & 5 & 21 & 27 & 16 & - & 20 & 4 & 21 & 23 & - & 61 & 84 \\ 3 & 1 & 8 & - & 6 & - & 5 & - & - & 1 & 1 & 8 & 5 & 16 & 7 & 6 & 3 & 15 & 1 & - & 5 & 1 & 4 & 73\end{array}$ $\begin{array}{llllllllllllllllllllllll}2 & 2 & 4 & 18 & 2 & 8 & - & 1 & 2 & - & - & 6 & 1 & 5 & 7 & 5 & 3 & 11 & 7 & 2 & 3 & 4 & -99\end{array}$ $\begin{array}{lllllllllll}3 & 11 & 3 & - & 5 & 18 & 1 & 2 & 36 & 9 & 7\end{array}$

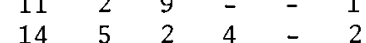

- 145

1

8

$-$


the lagoonal flats vegetation could be expected with the removal of this grazing pressure. Such changes are recorded for English dune slack communities as a result of reduction of grazing by rabbits (Ranwell 1960). The lagoon flat closed-herbfield is similar in environmental conditions and species composition to dune slack communities found elsewhere in Tasmania (e.g. Bowden and Kirkpatrick 1974), although the Lagoon Beach closed-herbfields may be the largest area of this vegetation type in Tasmania.

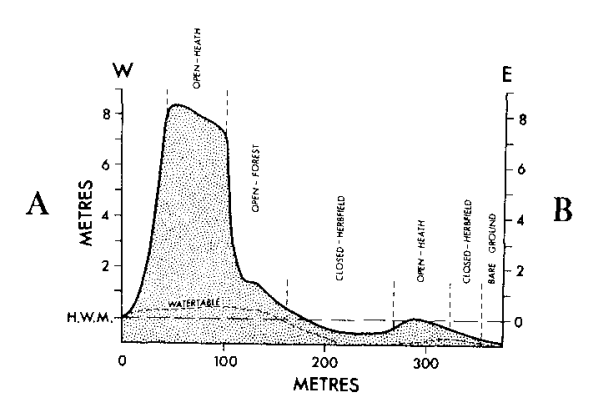

V.E. $=25$

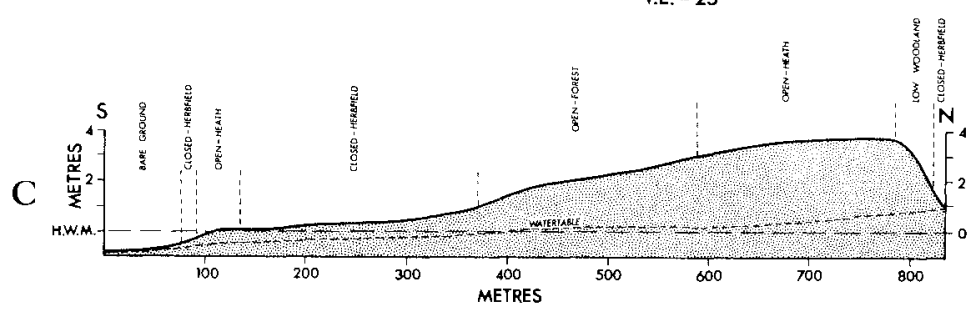

FIG. 4. - Results of the levelling traverses.
Other factors

that could be related to the occurrence of the closed-herbfield are salinity and nutrient availability. There could be movement of nutrients in the groundwater from surrounding areas into the flats. The nutrients would tend to remain in the soils of the flats $D$ in the absence of sustained leaching . The salinity of the soils of the flats, evidenced by the abundance of such species as Samolus repens and Selliera radicans, may prevent invasion by species adapted to waterlogging, but unable to withstand moderate salinity. A detailed study of these closed-herbfields could be most rewarding, especially as our knowledge of the ecology of the vegetation of the slack habitat type is somewhat scant (Ranwel1 1972).

Outside the lagoonal flats edaphic conditions seem to be the most important influence on vegetation. The open-heath and low woodland communities are found where there is a considerable depth of heavily leached sand overlying the bedrock, whereas the open-forest and open-scrub communities occur where the bedrock could be expected to be relatively close to the soil surface or where leaching of deep sands has not been severe, as in the patches of open-forest on the lee slopes of the foredune (fig.1). However, open-heath does occur on the young soils of the foredune, where exposure to saltspray and relative lack of moisture may be the major controlling factors. A1 so, low woodland occurs on the clifftops in the north of the study area (fig. 1) where the bedrock is close to the surface. However, in contrast to the other areas of low woodland, the community is dominated by Casuarina strieta (plate 3), a species whose resistance to the effects of saltspray often give it dominance of a narrow coastal strip, especially where soils have formed in situ.

The occurrence of low woodland may be partially controlled by water relations. It tends to occur in areas of low relief and altitude, and varies internally according to topographic position. In the most ill-drained parts of the low woodland species such as Eucalyptus ovata and Melaleuca squarrosa are common, while in the better drained areas Encalyptus amygdalina is dominant, and the subordinate species are those typical of dry heaths. The open heath-1ow woodland boundary may be partially controlled 


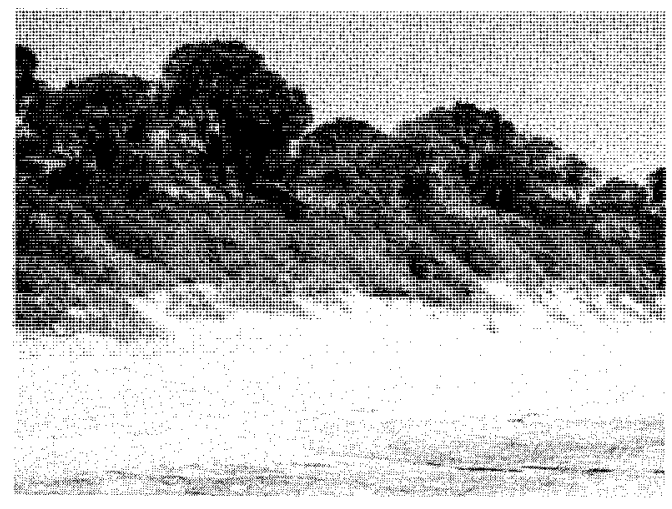

PLATE 3. - Pruned coastal shrubs on sand and Casuarina stricta low woodland on clifftop soils formed in situ on sandstone.

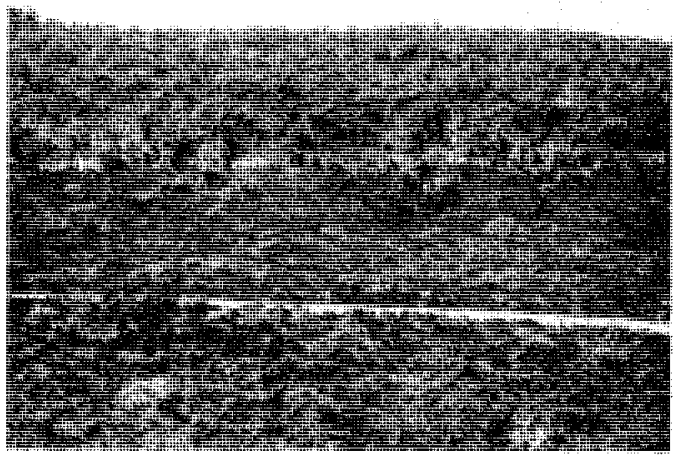

PLATE 4. - Open-heath with low woodland in the middleground and open-forest in the background.

by water relations, with the open-heath generally being found at higher elevation than the low woodland. The influence of saltspray and soil fertility related to the depth of sand may also be important. The most extensive area of open-heath occurs where the altitudinal difference between the top of the foredune and the land to its lee is sma11est. Asymmetry of form, possibly due to sodium chloride necrosis, is evident in the trees on the open heathmlow woodland interface (plate 4). Some of the areas mapped as open-heath (fig. 1) are floristically better considered part of the lagoon flat vegetation. The dominant species are Banksia marginata and Acacia verticizlata with the species of the ground stratum being those found abundantly on the flats. This type of open-heath occurs on similar soils to the closed-herbfield, but is found in slightly more elevated positions.

The open scrub-open forest boundary is probably the result of firing and saltspray. Eucalyptus viminalis, the dominant of the open-forest, has regenerated in the openscrub among dead trees of the same species. A fire may have removed the protection given to these now dead eucalypts by vegetation closer to the coast, and epicormic shoots may have been subject to sufficient sodium chloride necrosis to prevent recovery. However, seedlings have been able to establish in the shelter of the regenerating understory, and eventually, if no more fires ensue, the open-scrub could revert to open-forest.

\section{ACKNOWLEDGEMENTS}

The 1972 Geography III class at the University of Tasmania collected the quadrat data. Mrs. J. Townrow, Miss Jean Jarman and Professor W.D. Jackson aided in the identification of plant specimens, and $\mathrm{Mr}$. G. Van der Geer drew the figures.

\section{REFERENCES}

Bowden, A.R. and Kirkpatrick, J.B., 1974: The vegetation of the Rheban Spit, Tasmania. Pap. Froc. R. Soc. Tasm., 108, 199-210.

Bray, J.R. and Curtis, J.T., 1957: An ordination of the upland forest communities of southern Wisconsin. Ecol. Monogr., 27, 325-349. 
Bridgewater, P.B., 1971: Practica1 application of the Zurich-Montpel1ier system of phytosociology. Proc. Roy. Soc. Vict., 84, 255-262.

Churchi11, D.M. and de Corona, A., 1972: THE DISTRIBUTION OF VICTORIAN PLANTS. Dominion Press, North Blackburn.

Gauch, H.G. and Whittaker, R.H., 1972: Comparison of ordination techniques. Ecology, 53, 868-875.

Grizzle, J.E., 1967: Continuity correction in the Chi ${ }^{2}$ test for $2 \times 2$ tables. Am. Statist., 21, 28-32.

Ranwe11, D.S., 1960: Newborough Warren, Anglesey III. Changes in the vegetation on parts of the dune system after the loss of rabbits by myxomatosis. J. Ecol., $48,385-395$.

1972: ECOLOGY OF SALT MARSHES AND SAND DUNES. Chapman and Ha11, London.

Specht, R.L., 1970: Vegetation. in G.W. Leeper (Ed.). THE AUSTRALIAN ENVIRONMENT, 4 th ed., CSIRO and MUP, Melbourne.

APPEND IX

Species collected from Lagoon Beach

Nomenclature follows Churchill and de Corona (1972) except where authorities are given. Introduced species are marked with a cross.

DENNSTAEDTIACEAE: Pteridium esculentum.

JUNCAG INACEAE: Triglochin procera.

GRAMINEAE: Agrostis ?avenacea, +Ammophila arenaria, Danthonia setacea,

Deyeuxia ?quadriseta, Dichelachne rara R. Br., Stipa mollis R. Br., Tetrarrhena distichophyzza, +Vuzpia bromoides.

CYPERACEAE: Lepidosperma concavum, L. filiforme, L. Zongitudinale, Schoenus nitens, S. temuissimus, Scirpus nodosus.

RESTIONACEAE: Leptocarpus tenax, Hypolaena fastigiata.

CENTROLEPIDACEAE: Centrozepis fascicularis.

LILIACEAE: Dianelza revoluta, Lomandra Zongifolia.

ORCHIDACEAE: Spp.

CASUARINACEAE: Casuarina iittoralis, C. monilifera, C. stricta.

PROTEACEAE: Banksia marginata, Hakea teretifolia, Persoonia juniperina.

SANTALACEAE: Exocarpos strictus.

AIZOACEAE: Carpobrotus rossii.

CARYOPHYLLACEAE: Scleranthus bifloms.

LAURACEAE: Cassytha glabezza.

TREMANDRACEAE: Tetratheca pilosa.

PITTOSPORACEAE: Bilzardiera long iflora.

ROSACEAE: Acaena anserinifolia.

MIMOSACEAE: Acacia dealbata, A. melanoxyzon, A. suaveolens, A. verticilzata.

PAPILIONACEAE: Aotus ericoides, Bossiaea cinerea, B. prostrata, Daviesia ulicifolia, Dilluynia glaberrima, Gompholobium huegelii, Kennedia prostrata, Eultenaea

GERANIACEAE: daphnoides, $P$. dentata, Sphaerolobium viminew.

PXALIargonium austraze.

RUTACEAE : oxalis corniculata.

POLYGALACEAE:

EUPHORBIACEAE:

Correa alba.

RHAMNACEAE :

Comesperma calymega, C. volubize. Amperea xiphoc Zada. Pomaderris elliptica Labill. 


\section{J.B. Kirkpatrick}

DILLENIACEAE: Hibbertia acicularis, H. fasciculata.

HYPERICACEAE: Hypericum gromineum.

VIOLACEAE: Viola hederacea.

THYMELACEAE: Pimelea humilis, P. Zinifolia.

MYRTACEAE: Eucalyptus amygdalina Labill., E. ovata, E. viminalis, Leptospermum glaucescens, L. scoparium, Melaleuca squarrosa.

HALORAGACEAE: Haloragis mierantha, $H$. tetragyna, H. teucrioides.

UMBELLIFERAE: Hydrocotyle hirta.

EPACRIDACEAE: Astroloma humifusum, Epacris impressa, E. Zanuginosa, Leucopogon ericoides, L. parviflorus, L. virgatus, Sprengelia incarmata, Styphelia adscendens.

PR IMULACEAE:

CONVOLVULACEAE: Dichondra repens.

MYOPORACEAE: Myoporum insulare.

PLANTAGINACEAE: tPlantago coronopus.

CAMPANULACEAE: WahZenbergia ?tadgezzi $i$.

LOBELIACEAE: Pratia pedunculata.

GOODENIACEAE: Goodenia lanata, Scaevola hookeri, Selliera radicans.

STYLIDIACEAE: Stylidium grominifolium.

COMPOSITAE: Brachycome aculeata, Cassinia aculeata, Cotuza coronopifolia,

C. reptans, Craspedia glauca, tGnaphalium candidissimu, Helichrysum scorpioides, Hypochaeris glabra, $+H$. radicata, Lagenophora stipitata, +Leontodon taraxacoides, Serecio biserratus, S. minimus, tSonchus asper, S. megalocarpus. 
